\title{
CINDERELA SURDA: O SURDO E O SIMBÓLICO NO CONTO INFANTIL
}

\section{RESUMO}

lone Barbosa de Oliveira Silva iboliveira@ hotmail.com Universidade Estadual do Sudoeste da Bahia, Jequié, Brasil.

Francislene Cerqueira Alves

rancispib2008@hotmail.com

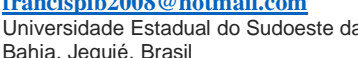

Jorgina de Cássia Tannus Souza jorgina_tannus@hotmail.com Centro de Apoio Pedagógico de Ipiaú, Ipiaú, Brasil

\begin{abstract}
O presente trabalho propõe-se a analisar o conto Cinderela Surda, de Hessel, Rosa e Karnopp (2007), a partir de sua representação e significados simbólicos. O conto analisado é uma releitura da tradicional Cinderela, de Perrault (1999) para a realidade dos surdos, ressaltando aspectos pertencentes à cultura e identidade surda. A partir deste conto, interessa-nos compreender e trazer à tona possíveis conflitos e dificuldades enfrentadas pela criança surda. Para isso, tivemos como suporte teórico Bettelheim (1980), Corso e Corso (2006) e Abramovich (1997) na abordagem acerca dos contos infantis e seu material simbólico e Goldfeld (2002), Quadros (1997) e Skliar (1997) no que se refere à criança surda. Compreendemos a partir da análise que a linguagem simbólica pode retratar conflitos internos enfrentados por crianças surdas, permitindo-as entender sobre si mesmas e encontrar significados para suas vidas. Além disso, percebemos a importância de uma literatura surda visando recuperar as tradições culturais de suas comunidades.
\end{abstract}

PALAVRAS-CHAVE: Cinderela Surda. Contos infantis. Criança surda. Conflitos internos. 


\section{INTRODUÇÃO}

$\mathrm{O}$ ato de contar história é uma atividade muito antiga e comum em todas as civilizações do mundo inteiro. Desde o início da humanidade temos relatos de contadores de histórias, como lendas, mitos e contos, pois mesmo antes de serem escritas essas histórias já existiam na forma oral e eram passadas de geração em geração. A partir do século XVII, surgem os primeiros registros dos contos de fada, que foram adaptados inicialmente por Charles Perrault e depois por muitos outros escritores, que foram construindo uma literatura específica para o público infantil.

Já a literatura para surdos, não temos notícias de quando surgiu, mas assim como as narrativas orais, as histórias contadas por surdos também eram passadas por gerações, em língua de sinais. Porém, como não tinha meios para registrar essas histórias (vídeos, textos com imagens, escrita) muitas delas foram esquecidas, porém algumas permanecem na memória de surdos.

Assim, quando falamos em literatura surda, estamos no referindo a algo mais recente. Pois o registro dessas histórias só foi possível, especialmente, com o reconhecimento da Libras como língua e do advento da tecnologia, e mais recentemente com o uso de uma escrita para a língua de sinais ${ }^{1}$.

Porém, apesar de atualmente falar-se em uma Literatura Surda, esse campo ainda é muito escasso de investigação, temos hoje histórias registradas em vídeos, livros, pesquisadores têm buscado registrar e tornar pública as narrativas, poemas, piadas contadas por surdos, mas as pesquisas ainda são ínfimas no trato dessas narrativas com crianças surdas.

São muitas as discussões sobre a importância dos contos infantis e seu benefício para a construção e formação da criança, porém percebemos neste itinerário de pesquisas uma lacuna quanto ao trabalho com crianças surdas e como estas crianças, que apreendem o mundo a partir de uma experiência visual, enxergam o mundo simbólico dos contos de fada. Pois, a experiência com o mundo fantástico e simbólico deve fazer parte do universo infantil, independente do perfil da criança.

Sabendo do valor simbólico dos contos na vida da criança e de como estes abordam seus dilemas mais interiores, encontramos em Cinderela Surda um rico arsenal simbólico, por várias razões: por representar a realidade surda, por retratar os problemas enfrentados pela criança surda e por refletir sobre a história, a língua e a identidade surda.

Acreditamos que, a partir do material simbólico presente no conto, é possível identificar nele algumas dificuldades e conflitos vividos pela criança surda, pois mesmo tratando-se de um conto, que é uma história no plano do maravilhoso, aborda aspectos reais da vida da criança. 


\section{A CRIANÇA SURDA E OS CONTOS INFANTIS}

Para Abramovich (1997), o primeiro contato que a criança tem com o texto é oralmente, por meio da voz da mãe, do pai ou avós, contando contos de fada, trechos da Bíblia, histórias inventadas e outras. Para a autora, as histórias são importantes para a formação de qualquer criança e é ouvindo que ela aprende a ter prazer pela leitura.

Nesse sentido, se considerarmos a realidade da criança surda, ela estará em desvantagem, pois por ser surda não receberá esse estímulo oral dos pais ou familiares, nem tão pouco sinalizado, já que, a maioria dos pais de surdos é ouvinte e não conhece a língua de sinais, meio pelo qual a criança surda teria contato com os contos infantis.

Por isso, a apreensão dos contos, geralmente, só acontecerá na escola com pessoas que conheçam a língua de sinais. É na escola que estas crianças terão seu primeiro contato com o mundo imaginário e a oportunidade de conhecer as histórias em sua língua, conhecer personagens, identificar-se com eles, e assim perceber o mundo mágico dos contos de fada. Para isso, a escola deve elaborar meios para, por meio dos contos, suscitar o imaginário dessas crianças e permitir o acesso à obra literária.

Porém, mesmo na escola regular os contos infantis são pouco explorados e muitas das histórias não contemplam a identidade das crianças surdas. Os contos apresentados nas escolas não tratam de pessoas surdas nem de sua identidade e cultura. Não são apresentadas às crianças surdas personagens surdas. Assim, fazse necessário investir em uma literatura infantil para crianças com surdez e, em especial, aos contos adaptados para língua de sinais e até mesmo as histórias contadas pelos próprios surdos, pois sabemos da importância dos contos para o desenvolvimento infantil e como estes são fundamentais no processo de autoconhecimento da criança.

Segundo Quadros (1997), uma escola venezuelana apresentou algumas metas para o desenvolvimento de crianças surdas filhas de pais ouvintes. Dentre essas metas destacamos:

Garantir que a criança surda construa uma teoria de mundo, pois a criança surda que convive com adultos ouvintes não tem chance de questionar as coisas, porque não obtém respostas. Quanto mais experiências de vida forem comentadas e elaboradas, amplia-se mais a concepção de mundo. (QUADROS, 1997, p.37)

Conforme Abramovich (1997), as histórias infantis ajudam a criança a encontrar respostas às suas perguntas e a esclarecer melhor as próprias dificuldades. Entendemos com isso que a criança surda em contato com os contos, pode obter essa construção de mundo e questionamentos de que fala Quadros (1997). Para que isso aconteça, deve haver mais pesquisas neste campo, tão escasso de investigação: criança surda e contos infantis.

Os contos têm um papel fundamental na construção do conhecimento de qualquer criança seja ela surda ou ouvinte. Dessa forma, é necessária uma aproximação entre os contos infantis e crianças surdas. Os contos infantis já que têm a oportunidade de vivenciar o contato com o mundo da fantasia e dos 
seres encantados. É papel, especialmente, da escola proporcionar essa aproximação.

Os elementos mágicos, os personagens, as batalhas enfrentadas pelo herói são instrumentos importantes que podem servir de ferramentas metodológicas que favorecem na educação da criança. Além de servir de estímulo para sua imaginação, retrata simbolicamente os conflitos vivenciados por estas crianças durante a infância.

De acordo com Quadros e Schmiedt (2006), o relato de histórias e a produção de literatura infantil em sinais são recursos muito importantes na alfabetização da criança surda, segundo as autoras ainda nas comunidades surdas existem contadores de histórias espontâneas, que são passadas de geração em geração, mas a produção artística dos surdos em língua de sinais não obteve a merecida atenção nas salas de aula.

Os relatos de histórias e a produção literária, bem como a interação espontânea da criança como outras crianças e adultos por meio da língua de sinais devem incluir aspectos que fazem parte desse sistema lingüístico. (QUADROS e SCHMIEDT, 2006, p.26).

$\mathrm{O}$ ato de contar histórias é muito comum em todas as culturas, inclusive na cultura surda. Os surdos, assim como os ouvintes, têm o hábito de contar histórias, mas infelizmente essas histórias não foram registradas e muitas delas perderam-se.

A comunidade surda tem como característica a produção de histórias espontâneas, bem como de contos e piadas que passam de geração em geração relatadas por contadores de histórias em encontros informais, normalmente, em associações de surdos. Infelizmente nunca houve preocupação de registrar tais contos. (QUADROS e SCHMIEDT, 2006, p.25).

Assim como os tradicionais contos infantis, os contos para surdos têm um valor significativo no ensino da criança surda. Entendemos que além das histórias infantis já conhecidas, também a literatura surda, apesar da ínfima quantidade, precisa ser explorada por essas crianças. $O$ uso dessas histórias em sala de aula revela-se uma ferramenta importante no processo de alfabetização da criança surda, além de ressaltar aspectos pertencentes a sua cultura e ampliar sua concepção de mundo. Conforme Quadros e Schmiedt (2006, p.25):

A produção de contadores de histórias naturais, de histórias espontâneas e de contos que passam de geração em geração são exemplos de literatura em sinais que precisam fazer parte do processo de alfabetização de crianças surdas. histórias criadas por surdos quanto as adaptações se apresentam como um rico material que podem contribuir com o desenvolvimento da criança surda.

Há algumas histórias criadas ou adaptadas por surdos e ouvintes, da comunidade surda, que foram recontadas a partir da cultura surda e abordam a 
temática surdez e língua de sinais como: Cinderela Surda (HESSEL, ROSA, KARNOPP, 2007) e Rapunzel Surda (SILVEIRA, ROSA, KARNOPP, 2005). O Som do Silêncio (COTES, 2004), Adão e Eva (ROSA; KARNOPP, 2005), Patinho Surdo (ROSA; KARNOPP, 2005), Tibi e Joca (BISOL, 2001) e A cigarra e as formigas (OLIVEIRA; BOLDO, 2003), Feijãozinho Surdo, Mãos Tagarelas bocas sorridentes, Um mistério a resolver: o mundo das bocas mexedeiras dentre outras.

O material, em geral, reconta a experiência das pessoas surdas, no que diz respeito, direta ou indiretamente, à relação entre as pessoas surdas e ouvintes, que são narradas como relações conflituosas, benevolentes, de aceitação ou de opressão do surdo. (KARNOPP, 2008, p.15)

Compreendemos que os contos infantis para surdos podem possibilitar a criança surda o conhecimento de si e de sua cultura, ajudando-a nas suas relações com os outros e com seus familiares. De acordo com Bettelheim (1980), os contos de fada orientam a criança para a descoberta da sua identidade e ainda sugere à criança as experiências que são necessárias para desenvolver ainda mais o seu caráter.

Por isso é tão importante que as crianças surdas leiam ou vejam histórias de personagens com os quais elas possam se identificar, para que elas entendam que não estão sozinhas, mas que existem pessoas com as mesmas especificidades que as suas e assim ajudá-las a construir uma cultura e identidade surda.

\section{CINDERELA SURDA: CONHECENDO A HISTÓRIA}

Cinderela ou Borralheira, como também é chamada, é um dos contos mais populares de todos os tempos e também o que mais sofreu adaptações. Sua versão mais antiga foi registrada na China no século IX, quando se tinha como costume enfaixar os pés das mulheres, o que provavelmente explica o fato de em Cinderela dar-se tanta ênfase ao pé e ao sapatinho, seja ele de ouro ou de cristal. Segundo Bettelheim (1980), os antigos chineses associavam a beleza e a atração sexual com um pezinho extremamente pequeno, que era sinal de virtude.

A história de Cinderela tem sido recontada por diversas culturas e transmitida por gerações, mas a versão mais conhecida é a do francês Charles Perrault (1999), que desde sua escrita no século XVII tem sido adaptada por muitos autores, inclusive para os cinemas como no caso da Walt Disney que difundiu ainda mais sua versão.

Com relação ao conto Cinderela Surda, é uma releitura da tão conhecida história de Cinderela. Segundo os autores, não se sabe quem contou pela primeira vez essa história, foi recontada pelos surdos: "Não sabemos quem contou esta história pela primeira vez. Ela foi sendo recontada entre os surdos e nós resolvemos registrar e divulgar este belo texto". (HESSEL, ROSA, KARNOPP, 2007, p.5). Foi publicada em 2007 pelos autores: Carolina Hessel Silveira; Lodenir Becker Karnopp e Fabiano Rosa. Cinderela Surda é recontada a partir da cultura surda, com elementos da identidade da comunidade surda, tendo como protagonista da história uma menina surda, por isso o nome Cinderela Surda. 
Nosso objetivo, nesse texto, é recontar essa história a partir de uma outra cultura,uma cultura surda. Assim, este livro foi construído a partir de uma experiência visual, com imagens, com o texto reescrito dentro da cultura e identidade surda e da escrita de sinais, conhecida também como singwriting. (HESSEL, ROSA, KARNOPP, 2007, p.3).

O conto está escrito em uma versão bilíngue, ou seja, em Língua Portuguesa e na escrita da língua de sinais (SignWriting) ${ }^{2}$, há também a indicação de que as palavras escritas em maiúsculo correspondem à língua de sinais, o que facilita aos leitores entender quando uma conversa está sendo oralizada ou sinalizada

No corpus em análise, Cinderela é surda e aprendeu a língua de sinais quando criança com a comunidade de surdos. Era filha de nobres franceses e após a morte de sua mãe, ainda quando criança, seu pai casa-se novamente. Assim como, em outras versões da história, o pai de Cinderela adoece e morre, deixando a doce menina aos cuidados da malvada madrasta e suas filhas.

Mesmo não estando entre as cinzas, Cinderela trabalhava muito e apenas ela limpava e cozinhava, porém sua madrasta e suas irmãs nunca estavam satisfeitas. A comunicação entre elas quase nunca acontecia, pois estas pouco sabiam da língua de sinais.

Chega à sua casa um convite do príncipe, convidando-as para o baile, ele queria encontrar uma moça para casar-se. A madrasta fica muito feliz, pois deseja que uma de suas filhas case-se com o príncipe.

No dia do baile, todas estão prontas e bem vestidas para irem à festa, com exceção de Cinderela. Esta implora para ir também, mas seu pedido é negado porque não possuía um belo vestido. Cinderela fica em casa triste e chorosa, mas surge uma fada, que prontamente lhe veste com um lindo vestido e Ihe dá um belo par de luvas. Em sua linda carruagem Cinderela vai à festa, sendo orientada pela fada a retornar antes da meia-noite.

No baile, Cinderela, pela sua beleza, chama a atenção de todos, especialmente do príncipe, que logo a convida para dançar. A menina, com ar de timidez, sinaliza que é surda e o príncipe surpreso responde que também é surdo.

Após dançarem a noite inteira, Cinderela percebe que já era quase meianoite e ao sair correndo, deixa para trás uma de suas luvas. O príncipe tenta avisá-la, mas ela estava tão assustada que não o viu.

No dia seguinte, os empregados do palácio recebem ordens de procurar a dona da luva, uma jovem surda, com a qual o príncipe se casaria. Ao chegar à casa de Cinderela, a madrasta mentiu dizendo que suas duas filhas eram surdas,

\footnotetext{
${ }^{2}$ SignWriting ou escrita de sinais, utiliza-se de símbolos para escrever qualquer língua de sinais no mundo inteiro. Foi criada em 1974, pela americana Valerie Sutton, mas começou a ser pesquisada aqui no Brasil apenas em 1996. Acredita-se que esta escrita pode trazer muitos benefícios ao surdo, pois com ela pode-se registrar a história da cultura surda, assim como suas histórias espontâneas, suas piadas e poemas. Assim, o conto Cinderela Surda é um dos primeiros livros no Brasil a ser apresentado na forma bilíngue, ou seja, em Língua Portuguesa e em SingWriting.
} 
mas ao provarem a luva, não serviu em nenhuma delas. Ao ver Cinderela na cozinha, o empregado do reino pediu para que ela também experimentasse, e quão surpresos ficaram quando viram que a luva serviu perfeitamente. Cinderela foi levada à presença do príncipe e eles casaram-se e foram muito felizes.

\section{CINDERELA SURDA E SEUS ELEMENTOS SIMBÓLICOS}

No livro A Psicanálise dos Contos de Fadas, de Bruno Bettelheim (1980), percebemos o quanto os elementos simbólicos presentes nos contos abordam sobre os muitos conflitos que as crianças enfrentam durante as diferentes fases de sua vida. Apesar da pouca idade, as crianças veem nesses contos personagens e histórias que refletem sobre certos momentos que elas estão vivendo.

A forma simbólica de representar os dilemas da criança é fundamental para que ela possa passar com segurança para as próximas fases da vida. Bettelheim (1980, p.50), afirma que "o conto de fadas oferece materiais de fantasia que sugerem à criança sob forma simbólica o significado de toda batalha para conseguir uma auto-realização, e garante um final feliz".

Com a criança surda não é diferente. A necessidade da mágica e da fantasia é de todas as crianças, sejam surdas ou ouvintes. Suas angústias e conflitos interiores sempre aparecerão, mesmo que de forma diferente, por isso, percebemos em Cinderela Surda, um rico arsenal simbólico que representa muitos dos conflitos internos enfrentadas pela criança surda.

O primeiro elemento a ser analisado é o fato de Cinderela ser surda. Somente há pouco tempo, como já mencionamos, é que surgiram as primeiras histórias cuja temática é sobre surdez e com a personagem principal surda. Assim como, há algum tempo, não era comum, encontrarmos em livros de histórias infantis uma protagonista negra, por exemplo.

Os surdos, como também negros e índios, fazem parte de grupos sociais minoritários e apesar de se falar tanto em inclusão e igualdade social, estes grupos ainda têm a necessidade de buscarem espaços na sociedade. No conto, o fato de Cinderela ser surda significa, dentre outros motivos, uma forma dos surdos garantirem sua participação na vida em sociedade.

O fato de Cinderela ser surda e conviver com pessoas ouvintes, que não conhecem ou sabem pouco a língua de sinais, também faz referência ao que é recorrente na vida de muitos surdos. Pois seus pais, em sua maioria, são ouvintes e não conhecem sua língua, o que dificulta a comunicação entre eles.

A falta de comunicação é um dos problemas enfrentados pelos surdos, como também a falta de aceitação dos próprios pais. No conto, a rejeição a Cinderela por parte da família, não é necessariamente por conta da surdez, pois em nenhum momento isso é demonstrado e também porque em todas as outras versões, Cinderela é tratada da mesma forma. Porém, o fato da madrasta e suas irmãs não usarem sinais com Cinderela, demonstra indiferença à sua surdez.

Os primeiros sentimentos dos pais e familiares, quando descobrem que têm um filho surdo, são muitos: de decepção, de rejeição, de confusão, de medo e até mesmo de culpa. 
Assim, às vezes, atitudes parentais que classificamos como falta de participação ou de envolvimento com a criança podem, de fato, significar a dificuldade que os pais estão sentindo naquele momento em entender o que é a surdez. Muito freqüentemente, também, consideramos a 'falta de aceitação' da surdez por parte dos pais e dos membros da família, quando, de fato, há falta de tempo da família para assimilar e se adaptar a uma nova situação, falta de informações sobre uma situação que é desconhecida para eles. (FRANÇOZO, 2003, p.87)

Os pais, por enfrentar uma experiência nova, sofrem, talvez por medo de não saber como lidar com este novo membro, que é "tão diferente". No entanto, o filho surdo, pode sofrer ainda mais, pois sente toda a indiferença de seus pais em relação a ele. Conforme Rossi (2003), enquanto bebê, antes do diagnóstico da surdez, a relação entre pais ouvintes e filho surdo é de muita afetividade, mas com a descoberta da surdez, essa relação muda quase radicalmente. A autora, ainda comenta sobre o comprometimento dessa relação:

A nossa prática vem nos mostrando que os pais, ao terem certeza da surdez de seu filho, passam a sentir 'pena' da criança olhando-a com tristeza, tendendo a se culparem e passando a se sentir pouco a vontade ao brincar com um filho que não escuta. Essa mudança de comportamento altera significativamente a relação entre mãe e filho, e compromete o vínculo com os pais. (ROSSI, 2003, p.101)

No caso de Cinderela, não foram os pais que mostraram indiferença ao fato de ela ser surda, pois no conto não relata a convivência entre eles, mas sim a madrasta e suas filhas. Cinderela sabia língua de sinais "aprendeu a Língua de Sinais Francesa com a comunidade de surdos, nas ruas de Paris" ${ }^{3}$ ( p.8), porém as pessoas que conviviam com ela sabiam pouco de sua língua, por isso "A comunicação entre elas era difícil, pois a madrasta e as irmãs só faziam poucos sinais" (p.12). Notamos porém que estas, mesmo sabendo um pouco de sinais, em nenhum momento é relatada uma conversa em língua de sinais com Cinderela. Ao contrário, no único momento em que falam com Cinderela é oralmente, ignorando a sua língua: “- Não, você não pode ir conosco! Você não tem roupa bonita!" (p.16). Referindo-se, assim, as difíceis lutas contra as imposições do oralismo e a busca em legitimar os sinais, como uma língua.

Ainda hoje, os surdos sofrem por conta disso, visto que estão inseridos em um ambiente de pessoas que falam o que eles não ouvem e a todo o momento as pessoas direcionam-se a eles gritando, falando alto como se assim eles fossem ouvir. Ou como se tivessem a obrigação de saber fazer leitura labial. Os surdos têm uma língua, como já dissemos, e precisam ser respeitados mesmo sendo uma minoria linguística.

Sabemos que as irmãs de Cinderela falaram oralmente com ela e não sinalizaram, porque na apresentação do livro os autores indicam que "as palavras Surda (Karnopp et al, 2007), para evitar repetições. Serão escritos apenas os números de páginas. 
em letras maiúsculas representam os sinais" ${ }^{4}$ (p.5). Como, quando Cinderela implora para ir ao baile: “- POR FAVOR, DEIXE-ME IR COM VOCÊS!” (p.16).

Uma figura importante surge: a fada, que simboliza a figura da mãe que morreu bondosa, angelical, que entende os problemas e tem uma solução para eles. Como era de se esperar, a fada sabe sinais, pois seria difícil imaginar alguém que compreendesse as dificuldades do surdo, entendesse seus dilemas e não pudesse ajudá-lo por não poder se comunicar. A figura da fada nos leva a dois questionamentos: A fada também é surda? Ou uma ouvinte que sabe sinais? De uma forma ou de outra, a atitude dela, simboliza a importância de entender e ser entendido, mostra-nos a importância de serem quebradas as barreiras da comunicação entre ouvintes e surdos.

Entretanto, o conto nos deixa pistas que indicam a possibilidade da fada ser ouvinte, isso porque nenhum personagem ouvinte foi denominado como tal, porém os surdos sim, "Cinderela e o Príncipe eram surdos" (p.6). Se a fada assim fosse, acreditamos que também os autores teriam explicitado o fato no texto.

Assim a fada sinalizou: "-NÃO CHORE, QUERIDA, SOU UMA FADA E QUERO AJUDÁ-LA. VOCÊ VAI AO BAILE, COM ROUPA BONITA, COM LUVAS ROSA, EM UMA LINDA CARRUAGEM COM CONDUTOR." (p.18).

A fada por simbolizar a figura da mãe, porque é aquela que atende os desejos e necessidades do filho, pode representar o desejo da criança surda em ter suas vontades realizadas pela sua mãe, em poder comunicar-se melhor com ela, entendê-la e ser entendida, poder perguntar e obter respostas sem barreiras na comunicação. A ordem da fada também expressa dedicação, cuidado e a preocupação dos pais com os filhos: "-À MEIA NOITE, VOCÊ DEVERÁ VOLTAR PRA CASA" (p.20). É o que também nos diz Bettelheim:

A ordem da fada madrinha de que Borralheira esteja em casa a uma certa hora, senão as coisas sairão erradas, no conto de Perrault, é semelhante à solicitação dos pais à filha para que não fique fora até tarde, devido ao medo do que possa suceder-lhe. (1980, p.305)

Quantas crianças surdas não desejariam receber orientações de seus pais em sinais, para não precisar adivinhar, o que sua mãe ou pai tentam lhe dizer por meio de gestos? A dificuldade de comunicação entre pais ouvintes e filhos surdos é um problema enfrentado pelos surdos, muitos pais ouvintes não sabem a língua de sinais, tornando a comunicação com seus filhos limitada.

O conto traz um fato importante na história dos surdos, que é demonstrado na forma como o príncipe aprendeu a língua de sinais "O rei e a rainha contrataram o mestre L'Epeé para ensinar a Língua de Sinais Francesa ao Príncipe herdeiro do trono" (p.8). Essa descrição do conto faz referência a um dado importante da história dos surdos. O Abade L'Epeé foi um dos primeiros estudiosos da educação dos surdos e um defensor do uso da língua de sinais, portanto um nome fundamental no cenário de transformações na educação dos surdos e para a criação da primeira Escola Pública para Surdos em Paris, em 1760.

L'Epeé se aproximou dos surdos que perambulavam pela rua de Paris, aprendeu com eles a língua de sinais e criou os 'Sinais

Página $\mid 23$

${ }^{4} \mathrm{O}$ que também será utilizado doravante neste texto. 
Metódicos', uma combinação da língua de sinais com a gramática sinalizada francesa. O Abade teve imenso sucesso na educação dos surdos e transformou sua casa em escola pública. (GOLDFELD, 2002, p.28-29)

Outro ponto que gostaríamos de destacar é a chegada de Cinderela à festa. Quando ela chega, logo o príncipe a convida para dançar e faz isto por meio de um gesto: "estendeu-Ihe a mão, convidando-a para dançar" (p.22). Cinderela imediatamente sinaliza que é surda, o que pode representar que antes de aceitar o convite para dançar, ela avisa das suas "limitações", nos remetendo a trajetória de preconceito e discriminação vivenciados pelos surdos. Mostrando o que muitos surdos vivenciam, a rejeição do outro.

Ao analisarmos a ilustração de Cinderela, perceberemos que no seu encontro com o príncipe, ela está com o dedo na boca e com ar de timidez, o que pode estar simbolizando a vergonha de falar que é surda. Muitos surdos por não aceitarem sua surdez ou com medo de serem rejeitados tem vergonha de dizer que são surdos especialmente aqueles que foram oralizados (estimulados para falar) e não usam a língua de sinais. Outros ainda, porque já sofreram preconceitos ou foram ridicularizados por usarem sinais, enfim, os motivos são inúmeros.

Apesar das discussões sobre surdo e surdez, muitos surdos ainda sofrem preconceitos, por aqueles que os tem como anormais. Muitas crianças ainda têm dificuldades de se relacionar com os colegas ou os amigos da vizinhança.

Os meus colegas não me aceitavam porque tinham receio que a surdez pegasse como uma doença contagiosa, eles tinham medo de falar comigo, achando que eu não iria compreender, sempre que estava na fila por ordem de chegada, às vezes a primeira, por morar próximo à escola, eles me puxavam pelos meus longos cabelos negros que estavam trançados como uma índia, me arrastavam e colocavam como última da fila; sem entender muito bem, eu aceitava as imposições. (VILHALVA, 2001, p.19 apud STRÖBEL, 2007, p.22).

Outra leitura que podemos fazer quando Cinderela sinaliza quem ela é: “SOU SURDA!" (p.22), é que ela está assim, afirmando sua identidade. Afirmar a identidade surda é aceitar ser surdo, que possui uma língua e costumes próprios. Significa dizer, que não é um "coitadinho", nem doente e nem deficiente, é surdo, conforme depoimento de um jovem surdo: "A identidade surda é aceitar ser surdo. Se a pessoa não aceita ser surda, só, não tem identidade própria. É... ele fica revoltado. Não aceita. Ele tem vergonha de ser surdo. Eu não... Eu não tenho vergonha de ser surdo". (SANTANA e BERGAMO, 2005, p.570)

Por causa dos muitos preconceitos sociais em relação ao surdo, infelizmente, ainda há a necessidade de reafirmarem sua identidade, de falar que não são doentes, anormais, defeituosos e nem privados de uma língua. Conforme depoimento de uma surda: "Para quem se habituou a virar a cabeça ao chamado de seu próprio nome, é talvez difícil entender. Sua identidade está dada desde o nascimento. Não têm necessidade de pensar nela, não se questionam sobre si mesmos". (LABOURIT, 1994, p.51 apud SANTANA e BERGAMO, 2005, p.569). 
Ainda na mesma cena, outro fato chama nossa atenção é o baile, quem adaptou a história não retirou a dança, o que pode parecer inconsistente já que surdo não dança. Surdo não dança? Há pensamentos de que por conta de não ouvirem a música o surdo não dança, mas pesquisas têm demonstrado que muitos surdos gostam de dançar. Além disso, muitas instituições de ensino têm utilizado a dança como ferramenta de ensino-aprendizagem dos surdos. Então, a dança não está tão distante do universo do surdo.

Nos bailes e festas promovidos pelas associações de surdos, geralmente, no salão há poucos sujeitos surdos dançando... Aqueles que dançam no salão... Dançam livres, a sua maneira, afinal, nesses bailes e festas de cultura surda não haver regras de ritmo musical correto e muitas vezes acontece que quando acaba a música, eles continuam dançando (STROBEL, 2008 p. 78).

No conto, o príncipe também é surdo, o que pode simbolizar o encontro com seus pares, a participação dos surdos em comunidade, o ato de compartilhar experiências, costumes, ideias. Ou pode representar o fato de que no meio de uma sociedade majoritária de ouvintes, também há espaço para as minorias.

O príncipe e Cinderela ficaram felizes em saber que o outro era surdo e conversaram a noite inteira, o que pode significar a fuga do isolamento social, que não foi uma escolha, pois Cinderela apesar de conviver com sua família não tinha com quem se comunicar e naquele momento ela e o príncipe podiam ser compreendidos. Não havia o impedimento da comunicação, já que os dois falavam a mesma língua. "Felizes, o príncipe e a Cinderela dançaram e conversaram a noite toda, sem perceber o tempo passar..." (p.22).

Outro episódio que também faz referência à vida em comunidade é quando mostra como Cinderela aprendeu sinais: "Cinderela era filha de nobres franceses e aprendeu a Língua de Sinais Francesa com a comunidade de surdos, nas ruas de Paris" (p.8). O que mostra como a maioria dos surdos aprende a língua de sinais. Os surdos necessitam viver em comunidade, associações, fazer parte de um grupo surdo, pois a convivência entre eles gera conhecimento, discussões, debates e lazer.

A comunidade surda tem como característica a produção de histórias espontâneas, bem como de contos e piadas que passam de geração em geração relatadas por contadores de histórias em encontros informais, normalmente em associações de surdos. (QUADROS e SCHIMIEDT, 2006, p.25).

Muitos surdos vivem em um isolamento social, pois mesmo dentro de sua casa, por serem nada ou pouco compreendidos, sentem-se sozinhos, deslocados, são tratados como estranhos, o que ocasiona para eles, uma experiência perturbadora como no caso de Cinderela, que apesar de ter irmãs e madrasta não tinha com quem conversar. A barreira que se instaurou entre surdos e ouvintes é muito mais pelo preconceito do que pela diferença de linguagem.

Outro elemento simbólico muito importante na história de Cinderela Surda é apresentado no momento da história em que ela sai do baile apressada, pois o que ela deixa para trás não é um sapatinho de cristal, como na versão de Perrault 
(1999), mas uma de suas luvas. Em Cinderela Surda a luva tem relação íntima com a mão, o que com certeza exprime muito mais significados para o surdo do que o pé. Já que a mão, para um surdo, significa mais do que um instrumento de trabalho, significa a possibilidade de explorar sua língua, sua cultura, sua identidade. A mão é o canal linguístico do surdo e é por meio dela que este compreende e interage com o mundo.

Em Cinderela tradicional ou Borralheira, Bettelheim (1980) comenta que o sapatinho de Cinderela é símbolo da vagina:

Um receptáculo pequenino dentro do qual se pode inserir uma parte do corpo de modo justo pode ser visto como um símbolo da vagina. Algo que é frágil e não deve se estivar porque romperia lembra-nos o hímem. (p.304)

Em 'Borralheira' o pezinho bonito exerce uma atração sexual inconsciente, mas em conjunto com um sapatinho belo e precioso (por exemplo, dourado) no qual o pé cabe confortavelmente. (p.308).

Ela o escolhe porque ele a aprecia nos aspectos sexuais 'sujos', aceitando amorosamente sua vagina na forma de sapato, e aprova o desejo dela por um pênis, simbolizado pelo pezinho que cabe no sapato-vagina. Por esta razão, o príncipe traz o lindo sapato para Borralheira e ela coloca seu pezinho dentro. (p.311)

Portanto, a relação em Cinderela tradicional pé-sapato simboliza não apenas o casamento, mas o ato sexual. Em Cinderela Surda não há esta relação entre pé e sapato, mas há luva e mão, que pode simbolizar o noivado, em que o noivo coloca aliança no dedo de sua noiva. A luva simbolizaria o anel, que colocada na mão de Cinderela significa a união entre eles. Ou até mesmo a própria relação sexual, pois assim como o sapato simboliza a vagina na análise de Bettelheim (1980), a luva também pode representá-la, já que a mão, que substitui o pépênis, cabe confortavelmente na luva, que substitui o sapato-vagina.

O príncipe, assim como em outras versões, procura Cinderela pelo seu fetiche sexual, isto porque ele não só procura uma moça surda, mas aquela cuja luva coubesse. Mesmo porque quando ele a convidou para dançar, não sabia que ela era surda, mas porque provavelmente ficou encantado com sua beleza.

No universo dos contos, há muitos desses príncipes, seduzidos por um objeto cuja presença é imprescindível para que uma mulher seja escolhida. Podem ser pés, que calcem determinado sapato: mãos, o objeto que orienta a busca é um anel [ou uma luva]; ou ainda um cabelo, geralmente dourado e trazido pelo vento que inspira a busca por sua dona. (CORSO e CORSO, 2006, p.114. Interferência nossa)

O príncipe além de encontrar em Cinderela os atributos sexuais para ser sua esposa, pôde ainda compartilhar com ela sua identidade, sua língua, pois se reconhecem como surdos e comungam da mesma cultura.

Quando o encarregado do reino chega à casa de Cinderela procurando uma moça surda, a madrasta mente dizendo-Ihe que suas filhas são surdas. Isso nos 
faz refletir sobre status, conveniência. A madrasta nunca se importou com Cinderela, mal se comunicava com ela, mostrava-Ihe desprezo e rejeição a ela e a sua língua, no entanto, quando percebe que ser surdo pode the trazer benefícios, seus conceitos "mudam".

Tal atitude pode simbolizar o percurso histórico do surdo. Foram muitos preconceitos, discriminação e até mesmo a proibição de utilizar uma língua espaço-visual que atendesse as suas especificidades linguísticas. A língua de sinais foi por muito tempo estigmatizada, considerada inferior. Mas enfim, os surdos garantiram o direito de falar em uma língua de sinais, direito garantido aqui no Brasil pela Lei Federal no 10.436, de 24 de abril de 2002, e continuam lutando para conquistar cada vez mais seu espaço.

\section{E ASSIM TERMINA NOSSA HISTÓRIA...}

Apesar de tão antigos, os contos infantis não param de encantar gerações. Com sua riqueza simbólica abordam temas que fazem parte dos conflitos enfrentados por todas as crianças e para alguns autores essas narrativas simbólicas têm o intuito de preparar a criança para as transformações da vida, como a maturação sexual e o casamento.

O conto analisado é uma versão da tradicional Cinderela de Perrault (1999) chamado Cinderela Surda e traz uma releitura caracterizando a cultura surda. Elementos como a língua de sinais, a história da educação do surdo e sua identidade são apontadas nessa história. Analisamos Cinderela Surda a partir de sua linguagem simbólica, observando como este conto representa a realidade dos surdos e algumas dos conflitos enfrentados por eles.

Compreendemos a partir da análise do conto, que seus elementos simbólicos refletem sobre a realidade da criança surda, visto que os conflitos representados em Cinderela Surda são comuns na vida das crianças com surdez como: a dificuldade da comunicação com os ouvintes, até mesmo os membros de suas famílias, a rejeição de seus parentes, o impedimento de falar em sua língua, o preconceito da sociedade em relação a sua surdez e o isolamento social. Assim, essa história pode ser explorada por pais, professores e educadores de surdos, pois este conto além de abordar temas pertinentes à criança e jovens surdos, evidencia a língua, a identidade e cultura surda.

Entendemos o quanto as sugestões simbólicas presentes em Cinderela Surda, podem ajudar as crianças surdas, não apenas no seu processo de alfabetização, mas na sua autoestima, aceitação, socialização, valorização de si e dos outros surdos. Visto que no desenrolar da história, o leitor é convidado a recorrer à história da sua cultura, ou até mesmo a sua própria história, assim é inevitável a identificação da criança surda com esse conto.

Ao longo do nosso trabalho percebemos o quanto os contos infantis são importantes para a formação e desenvolvimento da criança ouvinte ou surda. Além da importância desses contos tradicionais, há uma necessidade de investir mais em uma literatura surda, com o objetivo de alcançar de maneira mais efetiva a realidade dessa comunidade.

Torna-se relevante e necessário proporcionar a criança surda, histórias que façam referência a sua cultura. Pois sabemos que toda criança projeta-se, mesmo 
que inconscientemente, dentro dessas histórias. Para a criança surda é muito importante que no meio desse acervo de contos, com histórias apenas de/para ouvintes, ela veja histórias de/para crianças com especificidades como as suas.

A divulgação da literatura surda, representada em nosso trabalho por meio do conto analisado, é uma forma de recuperar as tradições culturais do indivíduo surdo, como também buscar afirmar sua identidade surda.

Não pretendemos parar por aqui, pois entendemos que este trabalho constituiu-se apenas uma parcela daquilo que desejamos levar adiante. As possibilidades de análises do conto não se findaram, visto que não dá para esgotar todas possíveis interpretações. Pois a cada leitura um diferente olhar, a cada leitor diferentes olhares e como diria Bettelheim (1980, p.28), “[...] só a própria estória permite uma apreciação de suas qualidades poéticas, e com isto uma compreensão de forma como enriquece uma mente suscetível". 


\title{
DEAF CINDERELLA: THE DEAF AND THE SYMBOLIC CHILDREN'S LITERATURE SHORT STORY
}

\begin{abstract}
This article aims to analyze "Deaf Cinderella" by Hessel, Rosa and Karnopp (2007) from its representation and symbolic meanings. This short-story is considered a traditional retelling of Cinderella by Perrault (1999) to the deaf reality, emphasizing issues pertaining to deaf culture and identity. We are interested in understanding and bringing out possible conflicts and difficulties faced by deaf children in this story. For that, we use as theoretical support Bettelheim (1980), Corso and Corso (2006) and Abramovich (1997) in approaching children's stories and the symbolic material present in these stories, and Goldfeld (2002), Quadros (1997) and Skliar (1997) regarding deaf children. We understand from this analysis that the symbolic language can describe internal conflicts faced by deaf children, allowing them to understand themselves and find meaning for their lives. We also want to reflect on the importance of children's tales and the need to invest in a deaf literature that aims to restore the cultural traditions of their communities.
\end{abstract}

KEYWORDS: Deaf Cinderella. Children's Literature. Deaf children. Internal conflicts. 


\section{REFERÊNCIAS}

ABRAMOVICH, Fanny. Literatura Infantil: gostosuras e bobices. São Paulo: Scipione, 1997.

BETTELHEIM, Bruno. A psicanálise dos contos de fadas. Trad. Arlene Caetano. 20. ed. Rio de Janeiro: Paz e Terra, 1980.

CORSO, Diana Lichtenstein. CORSO, Mário. Fadas no divã: psicanálises nas histórias infantis. Porto Alegre: Artmed, 2006.

FRANÇOZO, Maria de Fátima de Campos. Família surda: Algumas considerações aos profissionais que trabalham com famílias In: SILVA, Ivani Rodrigues; KAUCHAKJE, Samira; GESUELI, Zilda Maria. (Orgs.). Cidadania, Surdez e Linguagem: Desafios e realidade. 2. ed. São Paulo: Plexus Editora, 2003, p.77-96.

GOLDFELD, Márcia. A criança surda: linguagem e cognição numa perspectiva sociointeracionista. 3 ed. São Paulo: Pleux, 2002.

HESSEL, Carolina, ROSA, Fabiano, KARNOPP, Lodenir. Cinderela Surda. 2. ed. Canoas: Ulbra, 2007.

KARNOPP, Lodenir. Literatura Surda. Licenciatura em Letras-Libras. UFSC. Florianópolis, 2008.

PERRAULT, Charles. Contos de Perrault. Trad. Regina Régis Junqueira. Belo Horizonte: Vila Rica, 1999.

QUADROS Ronice Muller de. Educação de Surdos: a aquisição da linguagem. Porto Alegre, 1997.

QUADROS, Ronice Muller de; SCHMIEDT, Magali L. P. Idéias para ensinar português para aluno surdo. Brasília: MEC, SEEP, 2006.

ROSSI. Tereza Ribeiro de Freitas. Mãe ouvinte/Filho surdo: A importância do papel materno no contexto do brincar. In: SILVA, Ivani Rodrigues; KAUCHAKJE, Samira; GESUELI, Zilda Maria. (Orgs.). Cidadania, Surdez e Linguagem: Desafios e realidade. 2. ed. São Paulo: Plexus Editora, 2003, p.99-112. 
SANTANA, Ana Paula; BERGAMO, Alexandre. Cultura e identidade surdas: encruzilhada de lutas sociais e teóricas. Educ. Soc., Campinas, vol. 26, n. 91, p. 565-582, Maio/Ago. 2005. Disponível em: <http://www.cedes.unicamp.br>. Acesso em: 17 de julho de 2010.

STROBEL, Karin. As imagens do outro sobre a cultura surda. 2. ed. Florianópolis: UFSC, 2009.

Recebido: 07 abr. 2017

Aprovado: 13 mai. 2017

DOI: $10.3895 /$ rl.v19n24.5779

Como citar: SILVA, lone Barbosa de Oliveira; ALVES, Francislene Cerqueira; SOUZA, Jorgina de Cássia

Tannus. Cinderela surda: o surdo e o simbólico no conto infantil. R. Letras, Curitiba, v. 19, n. 24, p. 15-31, mar. 2017. Disponível em: <https://periodicos.utfpr.edu.br/rl>. Acesso em: XXX.

Direito autoral: Este artigo está licenciado sob os termos da Licença Creative Commons-Atribuição 4.0 Internacional. 